\title{
IF DARWIN WASN'T THE BEAGLE'S NATURALIST, WHY WAS HE ON BOARD?
}

\section{HAROLd L. BURSTYN*}

Professor Jacob W. Gruber has argued convincingly that Darwin was not the original Naturalist on H.M.S. Beagle's second voyage to survey the coasts of South America. ${ }^{1}$ The evidence, clearly marshalled by Gruber, shows that Robert McCormick, a Royal Navy surgeon, was appointed to the Beagle for the express purpose of making natural history collections, in addition to his primary duty as Ship's Surgeon. At first the two men got on well enough, going ashore together in the Azores to collect specimens. Then at the Beagle's second port of call in South America-Rio de Janeiro-Darwin moved into lodgings ashore. As a civilian, he had no duties on board ship, and he could further his collecting, since he wanted terrestrial rather than marine specimens, by staying in port while the ship sailed on its surveying mission in local waters.

The preferential treatment of Darwin by the Beagle's Captain, Robert FitzRoy, was too much for McCormick to take. He chose to be invalided back to England, there to find another ship, rather than to accept the fact that his official collections would be inferior to Darwin's private ones. McCormick had to wait until 1839 , when he was appointed Surgeon and Zoologist to H.M.S. Erebus, for the long sea voyage that would give him the opportunity to make his reputation in natural history. McCormick sailed for the Antarctic with Captain James Clark Ross just after Darwin's Fournal of researches - the account of the Beagle's voyage that McCormick might have written had he been granted FitzRoy's favour-brought its author public acclaim as a worthy British follower of Humboldt. No wonder McCormick could not bring himself to mention either Beagle or Darwin in his autobiography! In the pitiless eye of history it seems absurd that McCormick could have felt himself to be the equal of the man who overturned the accepted view of living nature. Had McCormick been more capable, he would have done more, on Erebus's Antarctic cruise from 1839 to 1843 , than merely support the researches of his Assistant Surgeon and Botanist, Joseph Hooker. Yet few men are prepared to allow to others a greater merit than they grant themselves; they prefer, as McCormick did, to blame their poor fortune on lack of influence. He must have felt that his glorious opportunity had been usurped by Charles Darwin.

His voyage on board the Beagle transformed Charles Darwin from an

\footnotetext{
* The William Paterson College, 300 Pompton Rd, Wayne, N.J. 07470, U.S.A. Contribution from the Woods Hole Oceanographic Institution No. 3068 .

' J. W. Gruber, 'Who was the Beagle's naturalist?', The British journal for the history of science, iv (1968-9), 266-82.
}

THE BRITISH JOURNAL FOR THE HISTORY OF SCIENCE Vol. 8 No. 28 (1975) 
ordinary intelligent young man, amiable but aimless, into a dedicated intellectual, determined to develop an insight that could overturn humanity's most cherished beliefs. If, as Gruber argues, McCormick rather than Darwin was the Beagle's naturalist, the historian of that fateful voyage must ask: what was Darwin doing on board? Though Gruber and others have suggested some tentative answers, they have not, in my opinion, got to the bottom of the matter. The answer to the question: if Darwin wasn't the Beagle's naturalist, what was he doing on board? turns out to be only distantly related to the science of his time. Darwin's importance to history arises, not from the circumstances that sent him on a voyage around South America, but from his transcendence of them. In Gruber's words, Darwin's 'ultimate contributions far exceeded any prior expectations'. ${ }^{2}$ I believe we have been blinded to the ordinariness of these expectations by the significance of Darwin's travels as revealed in the theory of natural selection. By viewing the Beagle's second voyage from the perspective of The origin of species, we have overlooked the reasons why Darwin was on board. To discover what these reasons were, we must turn to the Beagle's first South American surveying cruise.

Together with H.M.S. Adventure, the Beagle left England in May 1826 to survey the coasts of the newly independent nations of South America. Since a single sailing ship on a strange, uncharted coast could quickly come to grief, the British Admiralty sent two: Adventure was commanded by the senior of the two captains, Phillip Parker King; Beagle, by Pringle Stokes. 3 Though the ships could keep each other company, their captains could not, except when they reached port. Each followed the tradition of the Royal Navy by dining alone, so that an undue familiarity could not weaken his officers' total subordination to their captain's will. Completely responsible for the welfare of his ship and crew and the success of their mission, yet at the same time totally isolated from human contact except in the most formal terms, the captain of a surveying ship led an impossible existence at sea. The isolation of the captains of the Adventure and the Beagle increased once they had arrived on the coasts they were to survey, for the ships separated from each other for long periods in order to chart as much coastline as possible. During the Beagle's third year away from home, in the Southern Hemisphere winter of 1828 , Captain Stokes broke down during an arduous survey on the west coast of Chile. When the Beagle rejoined the Adventure at the end of July, Captain King was dismayed to find his subordinate in a deep depression. As the two ships' surgeons met aboard the Adventure to decide how to respond to King's question, whether

2 Ibid., p. 266.

3 Robert Fitz-Roy (ed.), Narrative of the surveying voyages of His Majesty's Ships Adventure and Beagle, between the years 1826 and 1836 (3 vols. in 4 , London, 1839 ), vol. $i$. Though this first volume was written almost wholly by King, FitzRoy was the editor since King had emigrated to Australia. FitzRoy wrote volume ii and its Appendix; Darwin wrote volume iii, later the famous Journal of researches. 
Stokes was fit for another cruise, Stokes shot himself in his cabin. He died two weeks later.4

King appointed the Beagle's First-Lieutenant, W. G. Skyring, to succeed the dead captain, expecting that the Commander-in-Chief on the South American Station, Admiral Sir Robert Otway, would ratify his choice. But when the Adventure and the Beagle reported to the flagship, H.M.S. Ganges, at Rio in December, Admiral Otway ordered his FlagLieutenant, Robert FitzRoy, to become the Beagle's new captain. Though Skyring had proved himself a competent commander during Stokes's illness and after his death, he had neither the family connexions nor the exceptional record of FitzRoy. A nephew of the famous Foreign Secretary, Viscount Castlereagh, on one side, a descendant of King Charles II through the Dukes of Grafton on the other, FitzRoy had distinguished himself both as Midshipman and Lieutenant, becoming 'one of the best practical seamen in the service'.5 Admiral Otway, who had served with Nelson, had personally plucked FitzRoy from one of the ships on the South American station to make him a staff officer. Now Otway gave the 23-yearold FitzRoy his first command.

During nearly two years that remained of the cruise of the Adventure and the Beagle, FitzRoy acquitted himself handsomely. Though Captain King of the Adventure and Lieutenant Skyring of the Beagle had reason to be displeased by Admiral Otway's choice, FitzRoy handled them with tact, and he proved himself a capable commander during the rest of the survey. Yet the strain on the young aristocrat must have been severe. Late in 1831, after more than a year at home in England, FitzRoy had his wish to return to South America fulfilled when he was ordered to take the Beagle back to complete the survey. But this time she would be without another ship to keep her company. FitzRoy may have had some second thoughts about the difficulties that isolation would impose on him. He was, as his most recent biographer puts it, 'a young and recently promoted captain in a Navy that was still Nelsonian and that accorded to its ships' commanders an altitude that was unapproachable and an authority that was absolute'. ${ }^{6}$ The strain of single-ship surveying had driven his predecessor Pringle Stokes to suicide, and FitzRoy may have begun to worry whether he had inherited the highly-strung character that had led his illustrious uncle Castlereagh to cut his own throat less than ten years before.7 Facing a voyage whose hardships would test him to the utmost, FitzRoy

4 Ibid., i. 150-I. See also G. S. Ritchie, The Admiralty chart. British naval hydrography in the nineteenth century (New York, 1967), pp. I 78-9. Captain Owen Stanley, T. H. Huxley's commander in H.M.S. Rattlesnake, also took his own life rather than return to an arduous Pacific survey. 5 The words are those of FitzRoy's junior shipmate, B. J. Sulivan, as quoted in H. E. L. Mellersh, FitzRoy of the Beagle (London, 1968), p. 26.

6 Ibid., p. 63.

7 G. J. Bartlett, Castlereagh (London, 1966). In a letter to his sister about FitzRoy's breakdown in 1834 , Darwin refers to FitzRoy 'being aware of his hereditary predisposition' to mental derangement; see Nora Barlow (ed.), Charles Darwin and the voyage of tha Beagle (London, 1945), p. 110 . See also the the text below at note 21 . 
sought some form of companionship to mitigate his isolation. If he admitted his plight to himself, then to seek a companion in the guise of a Civilian Naturalist was a useful fiction. In a period when private passengers, even captains' wives, were frowned upon, the Admiralty would never have entertained the idea of a gentleman companion. It seems equally likely that FitzRoy never dared let himself glimpse the reasoning behind his request to the Hydrographer, Captain Francis Beaufort, that a 'welleducated and scientific person' accompany him so 'that no opportunity of collecting useful information, during the voyage, should be lost'. ${ }^{8}$

Though the sequence of events by which Charles Darwin came to be FitzRoy's choice is too well known to linger over, a brief recapitulation is necessary in order to emphasize the evidence that FitzRoy's chief object was companionship. Gaptain Beaufort told his friend the Revd George Peacock, professor of astronomy at Cambridge, who in turn wrote to the Revd J. S. Henslow, his colleague the professor of botany. Henslow's first letter to Darwin made the situation clear: 'Capt. F. wants a man (I

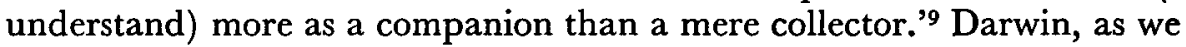
know, leaped at the opportunity until his father objected. One of Dr Robert Darwin's reasons for discouraging his son was 'That they must have offered to many others before [him] the place of Naturalist'ro aboard the Beagle. Though his brother-in-law Josiah Wedgwood could find no basis for it in the letters sent to Charles, ${ }^{1}$ I Robert Darwin's conjecture that his son was far down the list of candidates follows reasonably from the time sequence. One hardly decides late in August to seek someone for a voyage that begins in September. This particular objection of his father's had great importance for Charles. In the letter he wrote to announce that his father's opposition forced him to decline the invitation, Darwin began the second, final paragraph by asking his patron Henslow: 'What was the reason, that a Naturalist was not long ago fixed upon?'r2

Thanks to Professor Gruber, we now know that a naturalist had indeed been assigned to the Beagle in the person of her surgeon, McCormick, who had reported in July. The letter McCormick received from Professor Robert Jameson in November, ${ }^{13}$ after Darwin had already accepted FitzRoy's offer 'to be my guest on board', 14 shows that McCormick still considered himself to be the Beagle's naturalist long after Darwin had settled into the ship.

The next event in our story, Darwin's first attempt to communicate with FitzRoy, also supports the contention that the captain wanted a

8 FitzRoy, op. cit. (3), ii. 18.

9 Nora Barlow (ed.), Darwin ond Henslow: the growth of an idea. Letters $1831-60$ (Berkeley, 1967), p. 30 .

10 Ibid., p. 35 .

II Ibid., p. 36 .

12 Ibid., p. 33 .

13 Quoted in full in Gruber, op. cit. (1), Pp. 273-4, from the original in the Sherborn Collection of the British Museum.

14 FitzRoy, op. cit. (3), p. 19. 
companion. After his father consented to the voyage, Darwin went to Cambridge, from where a Mr Wood wrote to his kinsman FitzRoy on his friend Darwin's behalf. FitzRoy replied that he had already invited a friend to accompany him, a Mr Chester. The virtual absence of this name from the annals of natural history suggests that FitzRoy's offer came from his need for a companion rather than a naturalist. 15

When FitzRoy and Darwin met in September 1831, they hit it off at once. Both were ambitious young men in their twenties, FitzRoy four years Darwin's senior. Both were keen marksmen and riders. Chester, Darwin wrote to his sister, 'is in office and cannot go', ${ }^{16}$ so Darwin's way was clear to 'share such accommodations as [Captain FitzRoy] had to offer'. ${ }^{17}$ These accommodations consisted of the poop cabin, shared with two other officers, to sleep and keep his things in, and a seat in the Captain's cabin at which to eat and work. Darwin 'dined for the first time in [the] Captain's cabin \& felt quite at home' on I3 December, two days after the Beagle's first unsuccessful attempt to beat her way out of the English Channel. 'Of all the luxuries the Captain has given me', he wrote, 'none will be so essential as that of having my meals with him.' 18

The luxury was probably as much on the other side. No captain could keep his ship up to the mark as FitzRoy did and be on informal terms with his officers and men. In Darwin's words, the Beagle was 'the No. $I$ in South America ... a "sounding ship" [that could] beat a regular man-of-war' in 'doing . . . a perfect maneuver with . . . certainty and rapidity'. ${ }^{9}$ FitzRoy led his crew to as high a standard of surveying as of seamanship; modern charts are still based on Beagle's surveys. ${ }^{20}$ Had Dar-

13 The Royal Society's Catalogue of scientific papers, i (London, 1868 ), has one entry under 'Chester': John Chester's 'Treatise on the pilchard' published in the Transactions of the Cornwall Polytechnic Society for 1835 . It seems unlikely that a friend of FitzRoy's would be associated with a minor provincial society. A search of the author files of the Hunt Institute for Botanical Documentation, at Carnegie-Mellon University, which are more complete for this period than is the Royal Society Catalogue, has yielded no Chester at all.

The conventional interpretation, that FitzRoy invented a prior offer to put Darwin ofr, is based on the letter of 9 September ${ }_{1} 8_{31}$ from Darwin to his sister: '[FitzRoy] confesses his letter to Cambridge was to throw cold water on the scheme.' Though Darwin may have thought that 'Wood has been of the greatest use to me, and I am sure his personal introduction of me inclined Cap. Fitzroy to have me ... Wood ... solemnly warned Fitzroy that I was a Whig' (Barlow, op. cit. [7], pp. 46-7). Hence, conjectures Mellersh, Wood in fact did Darwin no service by uriting, for FitzRoy's reply announcing the prior offer was a direct response to his learning that Darwin was a Whig (Mellersh, op. cit. [5], p. 66). The nature of FitzRoy's offer to Chester-bona fide or invented - is not at issue here. Chester must have existed for his name to have been mentioned by FitzRoy; otherwise he would have left his friend nameless in the conversation with Darwin. That is, though FitzRoy may have invented the offer, the person to whom it was allegedly made had to be real for his name to be mentioned. Our question is then: was Chester a naturalist?; and our answer: not so far as we know.

16 Barlow, op. cit. (7), p. 43. Perhaps FitzRoy's friend was Harry Chester (1806-68), novelist and youngest son of Sir Robert Chester ( $1768-1848)$ of Bush Hall, Herts., in $18_{3} 1$ a clerk in the Privy Council Office; see Frederic Boase, Modern English biography, i (London, $189^{2}$ ), col. 604 .

I FitzRoy, op. cit. (3), ii. 18.

18 Nora Barlow (ed.), Charles Darwin's diary of the voyage of H.M.S. 'Beagle' (Cambridge, 15.34), p. 14.

19 Barlow, op. cit. (7), pp. 57,6r .

20 George Basalla, 'The voyage of the Beagle without Darwin', The mariner's mirror, xlix (1963), 42-8, especially note 19 . 
win been a less diligent naturalist on the voyage, had he even abandoned science on his return, he would still deserve a modest place in history for the companionship he provided FitzRoy on the long voyage. For the unspoken fears that drove FitzRoy to seek someone to be his friend on board ship were well grounded. The west coast of South America proved as trying to him as it had to his unfortunate predecessor Stokes. While Darwin was laid up in Valparaiso, suffering from an illness that kept him in bed for six weeks in the house of a friend, FitzRoy broke down, unable to complete the extensive survey his orders called for. Only when the Beagle's officers pointed out to him that he did not have to return to Tierra del Fuego did FitzRoy recover and resume his command.2I The instability of his mind is further demonstrated by his suicide in $186_{5}$.

My assertion that Charles Darwin sailed on the Beagle to provide her captain with companionship, principally at mealtime, is not entirely novel. Both Gruber and Mellersh have understood that the furthering of natural history was not FitzRoy's principal aim when he invited Darwin. But, in my opinion, they have not taken this insight far enough to see that natural history was just an afterthought. The essence of Gruber's claim, that McCormick was the Beagle's naturalist, lies in his statements that Darwin was 'the Captain's guest' whose 'position on board . . . was essentially that of a private passenger and companion to the Captain'.22 His biographer, H. E. L. Mellersh, goes even further into FitzRoy's motivation in writing to Beaufort: 'From a purely personal point of view FitzRoy was seeking a congenial companion to relieve the proverbial loneliness of the Captain, for whoever was chosen would mess alone with him in his cabin.' 23 Yet I believe that neither of these scholars has got to the heart of the matter. In Gruber's view, FitzRoy preferred Darwin, who was a gentleman, to McCormick, who was not, as an intimate. That is, in an age when naval surgeons held warrants rather than commissions, they were by definition of a different social class from naval officers, and the aristocratic FitzRoy would have been exceptionally conscious of this social distinction. To Mellersh, FitzRoy's choice of Darwin shows a strong interest in science, since otherwise the captain could have chosen the ship's artist to be his companion. I believe that the evidence shows natural history to have been of less importance for FitzRoy than these and other modern accounts of the Beagle's voyage suggest. More than modesty lies behind the view expressed by Darwin in later life 'that nobody was less qualified than he to fill the post of naturalist on the Beagle'.24 A better explanation than Mellersh's for FitzRoy's failure to make the artist his

¿ Darwin's account (Barlow, op. cit. [7], pp. 109-11) is fuller than FitzRoy's (op. cit. [3], ii. $36 \mathrm{I}-2$ ). Though his biographer calls FitzRoy 'the eternal masochist [who] left out nothing that might show himself in a bad light' (Mellersh, op. cit. [5], p. 191), he could not bring himself to state in print that he had relinquished his command for a short while.

32 Gruber, op. cit. (1), pp. 268, 270.

:3 Mellersh, op. cit. (5), p. 63 .

34 Gavin de Beer, Charles Darwin : a scientific biography (London, 1965), p. 56. 
confidant is found in Gruber's suggestion of social incompatibility. Augustus Earle, the artist, had the status of a servant rather than a gentlemanly equal since he was paid out of FitzRoy's own pocket. 25

However, the chief barrier between FitzRoy and McCormick was not social status. To see where the true importance of Darwin's companionship lay, we must go back to the kinds of relationships possible aboard a vessel of the Royal Navy. A captain's effectiveness depended upon his maintaining a superhuman stature. Though he might vent his feelings by abusing his officers, he could never be intimate with them. As Darwin put it in his Autobiography, FitzRoy 'was a man very difficult to live with on the intimate terms which followed from our messing by ourselves in the same cabin'.26

The difficulty of living on good terms with a Captain of a Man-of-War is much increased by its being almost mutinous to answer him as one would answer anyone else; and by the awe in which he is held-or was held in my time, by all on board. 27

In these circumstances, intimacy between Captain FitzRoy and his subordinate, the surgeon McCormick, would have been unthinkable, even had they come from identical social backgrounds.

The difficulties of relationships on board a small ship are seldom understood by landsmen. Even the perceptive Darwin was more than a month with his shipmates before he began to appreciate the constraints they placed on their behaviour. Dining with ship's officers in their Gunroom on Christmas Day I 831, two days before the Beagle succeeded, on her third attempt, in reaching the open Atlantic, Darwin caught his first glimpse of what their life was like. He wrote:

The officers are all good friends. Yet there is a want of intimacy, owing I suppose to gradation of rank, which much destroys all pleasure in their society. The probability of quarrelling and the misery on ship board consequent on it produces an effect contrary to what one would suppose; instead of each one endeavouring to encourage habits of friendship, it seems a generally received maxim that the best friends soon turn out the greatest enemies. It is a wonder to me, that this independence from one another, which is so essential a part of a sailor's character, does not produce extreme selfishness. I do not think it has this effect, and very likely answers their end in lessening the number of quarrels, which always must necessarily arise in men so closely united. Let the cause be what it may, it is quite surprising that the conversation of active intelligent men who have seen so much and whose characters are so early and decidedly brought out, should be so entirely devoid of interest. ${ }^{28}$

The isolation that destroyed Captain Stokes in 1828 and nearly destroyed Captain FitzRoy in 1834 could be broken for a Navy Captain by a

25 FitzRoy, op. cit. (3), ii. 19.

${ }^{26}$ Nora Barlow (ed.), The autobiography of Charles Daruin (New York, 1959), p. 73.

27 Ibid., p. 75.

${ }_{28}$ Barlow, op. cit. (1 8), p. 17. 
friendship only with someone totally outside the chain of command. No surgeon-naturalist could have filled that need. FitzRoy needed Darwin because Darwin was a civilian, and he needed him primarily on board ship. Once Darwin was initially settled on board, his excursions on shore were seldom made in FitzRoy's company. When the Beagle was in port, Darwin often moved ashore, even for brief stays. FitzRoy lived ashore occasionally, too, but apparently not with Darwin. At sea Darwin helped FitzRoy to keep his mind off his awesome responsibility, and Darwin did it in part by a deference of manner that both drove him in upon himself intellectually during the voyage and left him unwilling to see much of FitzRoy after their return. Though Darwin's voyage on the Beagle laid the foundations for his brilliant career in science, only with the hindsight of history does his studying and collecting take on significance. What Robert FitzRoy wanted when he met Charles Darwin was a gentleman to help him to bear the burdens of an arduous and isolated sea command, and the study of nature, in those far-off places he was sailing to, could provide an appropriate occupation for the captain's guest. Darwin was on board the Beagle to give the captain someone to relax with, someone to talk to who was wholly outside the rigid structure of naval discipline.

No one could have known, least of all the principals, as the Beagle set sail in I 83I, that FitzRoy's almost casual offer would change the course of human thought. In one of history's great ironies, the dogmatically religious FitzRoy chose for his table companion a man whose travels drove him to destroy the argument from design. The study of nature along the Beagle's route provided the captain with a polite fiction to explain his guest's presence and an activity attractive enough to lure a gentleman on board for a long voyage. Only the genius of Charles Darwin made the Beagle's second survey of South America one of the great events in the history of man's knowledge of the natural world. This proud young man was forced each day to take his meals with a religious fanatic who was under the heavy strain of a difficult sea command. Darwin could not argue as an equal with FitzRoy without the risk both of being insubordinate and ungrateful and of pushing the captain towards a breakdown. So the younger man turned in upon himself, and in the depths of his own mind Darwin developed a largeness of vision that only geniuses can muster. Charles Darwin found his own way to get back at his dogmatic captain. In a lifelong effort to vindicate the hypothesis of his grandfather, he demonstrated that biology could not be a science until it accepted the theory of organic evolution. 